\title{
Effects of Intraruminal Infusion of Sodium, Potassium, and Ammonium on Hypophagia from Propionate in Lactating Dairy Cows
}

\author{
M. Oba ${ }^{1}$ and M. S. Allen \\ Department of Animal Science, \\ Michigan State University, \\ East Lansing 48824-1225
}

\section{ABSTRACT}

The objective of this experiment was to evaluate effects of salt type on hypophagic effects of intraruminal infusion of propionate in lactating dairy cows. Our working hypothesis is that oxidative metabolism of propionate causes satiety by increasing hepatic ATP concentration and decreasing the discharge rate of the hepatic vagus. We hypothesized that hypophagic effects of propionate are reduced by ammonium and potassium. We speculated that ammonium infusion lowers hepatic ATP concentration because ATP is used for urea synthesis and potassium increases the discharge rate of the hepatic vagus. Eight ruminally cannulated Holstein cows in midlactation were used in a duplicated $4 \times$ 4 Latin square design experiment. Treatments were intraruminal infusion of propionic acid, ammonium propionate, sodium propionate, and potassium propionate. Treatment solutions were $0.93 M$ for propionate and $0.67 M$ for salts among the treatments except for propionic acid. Treatment solutions were infused over $14 \mathrm{~h}$ starting $2 \mathrm{~h}$ before feeding at $17.9 \mathrm{ml} / \mathrm{min}$, which is equivalent to 16.7 and $11.9 \mathrm{mmol} / \mathrm{min}$ for propionate and salts, respectively. Infusion of ammonium propionate decreased dry matter intake compared with sodium propionate and potassium propionate $(P<0.04$; 11.0 vs. 14.0 and $13.9 \mathrm{~kg} / 12 \mathrm{~h}$ ) by decreasing meal frequency without affecting meal size, indicating that ammonium delayed the sense of hunger. No difference in DMI and feeding behavior was observed between infusion of sodium and potassium propionate. Contrary to the hypothesis, ammonium infusion did not reduce hypophagic effects of propionate, possibly because the urea cycle indirectly stimulated oxidative metabolism in the liver by generating oxidizable carbon from amino acid catabolism.

Received August 5, 2002.

Accepted October 25, 2002.

Corresponding author: M. S. Allen; e-mail: allenm@msu.edu.

${ }^{1}$ Current address: Department of Animal and Avian Sciences, University of Maryland.
(Key words: propionate infusion, ammonium, urea synthesis, feeding behavior)

Abbreviation key: ME = metabolizable energy, MUN $=$ milk urea nitrogen

\section{INTRODUCTION}

Increasing ruminal fermentation is desirable to maximize microbial protein production and energy intake in high-producing dairy cows. However, greater ruminal fermentation sometimes decreases feed intake, and excess propionate production in the rumen is considered to have a direct hypophagic effect (Allen, 2000). Choi and Allen (1999) showed that meal size, intermeal interval, and DMI were not affected by infusion of acids compared to salts, indicating that ruminal $\mathrm{pH}$ per se does not have direct hypophagic effects. In that experiment, infusion of acetate resulted in meal size similar to iso-osmotic infusions of $\mathrm{NaCl}$. It was concluded that acetate affects satiety by mechanisms related to osmotic effects in the rumen. However, infusion of propionate decreased meal size and DMI and increased intermeal interval compared to infusion of acetate, providing evidence for specific hypophagic effects of propionate. Anil and Forbes $(1980,1988)$ suggested that propionate decreases feed intake by a mechanism via the hepatic vagus, but the actual mechanism for regulation of feed intake by propionate has not been elucidated.

Allen (2000) proposed that propionate decreases feed intake of ruminants by stimulating oxidative metabolism in the liver. Oxidative metabolism in the liver was shown to affect satiety in rats (Langhans et al., 1983, 1984, 1985a), and a temporal relationship between feeding behavior and hepatic ATP concentration has been demonstrated (Koch et al., 1998). Langhans et al. (1985a) proposed that oxidative metabolism in the liver affects feed intake by hyperpolarizing cell membrane potentials. The sodium pump inhibitor, ouabain, increased feed intake in rats when injected intraperitoneally (Langhans and Scharrer, 1987). Satiety signals originating in the liver are mediated by hepatic vagal afferents (Langhans et al., 1985b; Anil and Forbes, 1988), and Niijima (1983) reported that discharge rates 
of hepatic vagal afferents were reduced by glucose infusion in a dose-dependent manner in guinea pigs. These observations suggest that oxidative metabolism within hepatocytes generates ATP and decreases the discharge rate of hepatic vagal afferents, resulting in satiety, possibly by increasing sodium pump activity and hyperpolarizing membrane potential of nerve cells.

Our long-term goal is to alleviate hypophagic effects of propionate by formulating diets that modulate the metabolic or neural pathway by which propionate causes satiety. If propionate metabolism in the liver generates satiety signals by increasing hepatic ATP concentration, hypophagic effects of propionate can be alleviated by reducing hepatic ATP concentration. It was hypothesized that infusion of ammonium reduces the hypophagic effects of propionate because urea synthesis consumes ATP in the liver. In addition, if decreased discharge rate of hepatic vagal afferents sends a satiety signal to the brain, increasing their discharge rate can alleviate hypophagic effects of propionate. Further, it was hypothesized that infusion of potassium increases feed intake by increasing the discharge rate of vagal afferents compared with infusion of sodium. Infusion of potassium might decrease the potassium gradient across the membrane of vagal afferents, reducing potassium efflux, depolarizing the resting transmembrane potential of vagal afferents and increasing their discharge rate.

The objective of this experiment was to evaluate effects of salt type on hypophagic effects of intraruminal infusion of propionate in lactating dairy cows.

\section{MATERIALS AND METHODS}

Experimental procedures were approved by the All University Committee on Animal Use and Care at Michigan State University. Eight multiparous Holstein cows (143 \pm 26 DIM; mean \pm SD) cannulated ruminally for previous experiments were selected from the Michigan State University Dairy Cattle Teaching and Research Center. Experimental diets contained dry cracked corn (mean particle size of $3.6 \mathrm{~mm}$ ), corn silage, alfalfa silage, a premix of protein supplements (soybean meal, distillers grains, and blood meal), and a premix of minerals and vitamins (Table 1). Dietary NDF, CP, and starch concentrations were 29.0, 15.9, and 30.8\%, respectively. Dry cracked corn was the major source of starch to minimize propionate production from the basal diet. Means for BW, BCS [(Wildman, 1982); a five-point scale, where $1=$ thin to $5=$ fat], DMI, and milk yield before the experiment were $623 \mathrm{~kg}, 2.6,25.4$ $\mathrm{kg} / \mathrm{d}$, and $36.4 \mathrm{~kg} / \mathrm{d}$, respectively. Cows were assigned to duplicated $4 \times 4$ Latin squares balanced for carryover effects.
Table 1. Ingredients and nutrient composition of experimental diets (percentage of dietary DM except for DM).

\begin{tabular}{|c|c|}
\hline \multicolumn{2}{|l|}{ Diet ingredients } \\
\hline Corn silage & 27.0 \\
\hline Alfalfa silage & 25.4 \\
\hline Dry cracked corn & 25.9 \\
\hline Whole linted cottonseed & 6.8 \\
\hline Protein mix ${ }^{1}$ & 9.9 \\
\hline Vitamin $\&$ mineral $\operatorname{mix}^{2}$ & 5.0 \\
\hline \multicolumn{2}{|l|}{ Nutrient composition ${ }^{3}$} \\
\hline DM & 49.5 \\
\hline $\mathrm{OM}$ & 93.0 \\
\hline Starch & 30.8 \\
\hline NDF & 29.0 \\
\hline $\mathrm{ADF}$ & 20.8 \\
\hline $\mathrm{CP}$ & 15.9 \\
\hline Ether extract & 3.8 \\
\hline Forage NDF & 21.2 \\
\hline Metabolizable energy (Mcal/kg) & 2.72 \\
\hline $\mathrm{Ca}$ & 0.82 \\
\hline $\mathrm{P}$ & 0.56 \\
\hline $\mathrm{Mg}$ & 0.31 \\
\hline $\mathrm{K}$ & 1.50 \\
\hline $\mathrm{Na}$ & 0.19 \\
\hline $\mathrm{Cl}$ & 0.37 \\
\hline $\mathrm{S}$ & 0.21 \\
\hline
\end{tabular}

${ }^{1}$ Protein mix contained $75 \%$ soybean meal, $20 \%$ distillers grains, and $5 \%$ blood meal.

${ }^{2}$ Vitamin \& mineral mix contained $66.4 \%$ dry ground corn, $20.8 \%$ dicalcium phosphate, $7.8 \%$ salt, $2.3 \%$ magnesium oxide, $1.9 \%$ trace mineral (Co, Cu, Fe, I, Mn, Zn, and Se) premix, $0.7 \%$ vitamin $\mathrm{ADE}$ premix.

${ }^{3}$ Metabolizable energy and macrominerals were calculated from book values according to NRC (1989).

Treatments were continuous intraruminal infusion of mixtures of propionic acid alone or with bicarbonate salts $\left(\mathrm{NH}_{3}, \mathrm{Na}\right.$, or K). Treatment solutions were prepared by diluting 16.8 moles of propionic acid and 12.0 moles of bicarbonate salts $\left(\mathrm{NH}_{3}, \mathrm{Na}\right.$, or $\left.\mathrm{K}\right)$ to $18 \mathrm{~L}$ with deionized water. Bicarbonate salts were used instead of hydroxide salts to maximize the purity of treatment salts; the purity of commercially available potassium hydroxide was approximately $85 \%$, whereas the purity of potassium bicarbonate was $99.9 \%$. Control treatment was propionic acid without any bicarbonate salts. The concentration of propionate was $0.93 M$ across treatments, and concentration of salts was $0.67 M$ across treatments except for control. Solutions were infused at a rate of $15 \mathrm{~L}$ over $14 \mathrm{~h}$. The infusion rate of 17.9 $\mathrm{ml} / \mathrm{min}$ is equivalent to 16.7 and $11.9 \mathrm{mmol} / \mathrm{min}$ for propionate and salts, respectively. This rate of propionate infusion decreased DMI significantly in a previous experiment (Oba and Allen, 2003a) and was selected to evaluate how salt type affects hypophagic effects of propionate in this experiment. The concentration of salts was less than propionate to avoid the risk of ammonia toxicity for the ammonium treatment; the total amount of ammonium infused into the rumen was equivalent to $875 \mathrm{~g}$ of $\mathrm{CP}$ over $14 \mathrm{~h}$. Solutions were 
infused using four-channel peristaltic pumps (\#7801630, Cole-Parmer Instrument, IL) and Tygon tubing (7.5 $\mathrm{m} \times 1.6 \mathrm{~mm}$ i.d.). Treatment periods were $2 \mathrm{~d}$ with 14 $\mathrm{h}$ of infusion followed by $34 \mathrm{~h}$ of recovery.

Throughout the experiment, cows were housed in tie stalls and fed once daily $(1030 \mathrm{~h})$ at $110 \%$ of expected intake. Cows were not allowed access to feeds between 0830 to $1030 \mathrm{~h}$. The amount of feed offered and orts were weighed for each cow daily. On every infusion day, samples of all dietary ingredients $(0.5 \mathrm{~kg})$ were collected, and cows were infused treatment solutions from 0830 to $2230 \mathrm{~h}$. Cows were milked twice daily in the milking parlor except for the evening milking on infusion days when cows were milked in their stalls. Feeding behavior was monitored from 1030 to $2230 \mathrm{~h}$ on each infusion day by a computerized data acquisition system (Dado and Allen, 1993). Data of chewing activities, feed disappearance, and water consumption were recorded for each cow every $5 \mathrm{~s}$, and meal bouts, interval between meals, meal size, eating time, ruminating time, and total chewing time were calculated. Milk yield was recorded, and milk samples were taken at both milkings on each infusion day. Milk samples were analyzed for fat, true protein, lactose, SNF, and milk urea nitrogen (MUN) concentration with infrared spectroscopy by Michigan DHIA (East Lansing). Milk energy output was determined from milk yield and milk fat, protein, and lactose concentrations according to NRC (2001).

Diet ingredients were dried in a $55^{\circ} \mathrm{C}$ forced-air oven for $72 \mathrm{~h}$ and analyzed for DM concentration. All samples were ground with a Wiley mill (1-mm screen; Authur Thomas, Philadelphia, PA) and analyzed for ash, NDF, $\mathrm{ADF}, \mathrm{CP}$, and starch. Ash concentration was determined after $5 \mathrm{~h}$ of oxidation at $500^{\circ} \mathrm{C}$ in a muffle furnace. Concentrations of NDF and ADF were determined according to Van Soest et al. (1991; method A for NDF). Crude protein was analyzed according to Hach et al. (1987). Starch was hydrolyzed by an enzymatic method (Karkalas, 1985) after samples were gelatinized with sodium hydroxide. Following hydrolysis, glucose concentration was measured using a glucose oxidase method (Glucose kit \#510; Sigma Chemical Co., St. Louis, MO), and absorbance was determined with microplate reader (SpectraMax 190, Molecular Devices Corp., Sunnyvale, CA). Concentrations of all nutrients except for DM were expressed as percentages of DM determined by drying at $105^{\circ} \mathrm{C}$ for at least $8 \mathrm{~h}$ in a forced-air oven. Corn grain was dry sieved through eight sieves (Sieve apertures: 4750, 2360, 1180, 600, $300,150,75 \mu \mathrm{m}$, and bottom pan), using a sieve shaker (model RX-86, W. S. Tyler, Inc., Gastonia, NC) for approximately 20 min until the bottom pan weight was constant, and mean particle size of corn grain was calculated (ASAE, 1968).

All data were analyzed using the fit model procedure of JMP (version 4, SAS Institute, Cary, NC) according to the following model:

$$
\mathrm{Y}_{\mathrm{ijkl}}=\mu+\mathrm{S}_{\mathrm{i}}+\mathrm{C}\left(\mathrm{S}_{\mathrm{j}(\mathrm{i})}+\mathrm{P}_{\mathrm{k}}+\mathrm{T}_{1}+\operatorname{Cov}_{\mathrm{INF}}+\mathrm{e}_{\mathrm{ijkl}}\right.
$$

where

$$
\begin{aligned}
\mu= & \text { overall mean, } \\
\mathrm{S}_{\mathrm{i}}= & \text { fixed effect of square }(\mathrm{i}=1 \text { to } 2) \\
\mathrm{C}(\mathrm{S})_{\mathrm{j}(\mathrm{i})}= & \text { random effect of cow nested in a square } \\
& (\mathrm{j}=1 \text { to } 4), \\
\mathrm{P}_{\mathrm{k}}= & \text { fixed effect of period }(\mathrm{k}=1 \text { to } 4), \\
\mathrm{T}_{1}= & \text { fixed effect of treatment }(\mathrm{l}=1 \text { to } 4), \\
\operatorname{Cov}_{\mathrm{INF}}= & \text { effect of actual amount of solution infused } \\
& \text { into the rumen, and } \\
\mathrm{e}_{\mathrm{ijkl}}= & \text { residual, assumed to be normally distrib- } \\
& \text { uted. }
\end{aligned}
$$

One pump was used for each square of four cows, and the random effect of cow was nested within a square that shared the same infusion pump. Interactions of square $\times$ treatment and period $\times$ treatment were evaluated, but they were removed from the statistical model because interactions were not significant for response variables of interest. Volume of solution infused into the rumen was included in the statistical model as a covariate. Orthogonal contrasts included the effect of salts (acid only vs. $\mathrm{NH}_{3}, \mathrm{Na}$, and $\mathrm{K}$ ), the effect of ammonium $\left(\mathrm{NH}_{3}\right.$ vs. $\mathrm{Na}$ and $\left.\mathrm{K}\right)$, and the effect of mineral type (Na vs. K). The effect of ammonium treatment was compared with sodium and potassium treatments, and the effect of mineral type was compared between sodium and potassium treatments rather than with propionic acid treatment. This is because osmolarity and $\mathrm{pH}$ of infusates were similar among ammonium, sodium, and potassium treatments, and treatment effects can be attributed to a specific effect of ammonium or mineral type for each comparison. Treatment effects were declared significant at $P<0.05$, and a tendency for treatment effects was declared at $P<0.10$.

\section{RESULTS AND DISCUSSION}

Volume of solution infused into the rumen was slightly greater for propionate salts compared with propionic acid treatment and for sodium and potassium propionate compared to ammonium propionate treatment $(P<0.01$; Table 2$)$. This was unexpected because a four-channel peristaltic pump was used for each square with identical tubing and fittings, but a difference in viscosity of infusates might have affected flow rate. 
Table 2. Effects of intraruminal infusion of propionate salts on feeding behavior.

\begin{tabular}{|c|c|c|c|c|c|c|c|c|}
\hline & \multicolumn{4}{|c|}{ Treatments } & \multirow[b]{2}{*}{$\mathrm{SE}$} & \multicolumn{3}{|c|}{$P$ value } \\
\hline & Control $^{1}$ & Ammonium & Sodium & Potassium & & $\mathrm{A}^{2}$ & $\mathrm{~B}^{3}$ & $\mathrm{C}^{4}$ \\
\hline Actual volume infused (L) & 14.9 & 15.0 & 15.2 & 15.2 & 0.2 & $<0.01$ & $<0.01$ & 0.90 \\
\hline \multicolumn{9}{|l|}{ Eating behavior } \\
\hline DMI (kg/12 h) & 11.8 & 11.0 & 14.0 & 13.9 & 1.2 & 0.37 & 0.04 & 0.97 \\
\hline ME intake ${ }^{5}($ Mcal/12 h) & 36.3 & 35.0 & 40.2 & 40.1 & 3.6 & 0.55 & 0.18 & 0.98 \\
\hline Meal bouts (/12 h) & 5.7 & 5.6 & 8.0 & 7.2 & 0.8 & 0.10 & 0.02 & 0.39 \\
\hline Intermeal interval (min) & 94.5 & 105.0 & 62.8 & 73.9 & 12.1 & 0.24 & $<0.01$ & 0.42 \\
\hline Meal size (kg DM) & 2.3 & 2.1 & 1.8 & 2.2 & 0.3 & 0.33 & 0.73 & 0.33 \\
\hline \multicolumn{9}{|l|}{ Chewing time } \\
\hline Eating (min/12 h) & 133 & 124 & 157 & 161 & 14 & 0.32 & 0.03 & 0.82 \\
\hline$(\mathrm{min} / \mathrm{kg} \mathrm{DMI})$ & 11.5 & 11.7 & 11.2 & 11.6 & 0.6 & 0.98 & 0.52 & 0.54 \\
\hline Ruminating (min/12 h) & 228 & 165 & 163 & 175 & 15 & $<0.001$ & 0.80 & 0.54 \\
\hline$(\mathrm{min} / \mathrm{kg} \mathrm{DMI})$ & 19.6 & 15.0 & 11.7 & 12.9 & 1.2 & $<0.001$ & 0.06 & 0.43 \\
\hline Total $(\min / 12 \mathrm{~h})$ & 361 & 289 & 321 & 337 & 26 & 0.11 & 0.18 & 0.62 \\
\hline$(\min / k g \mathrm{DMI})$ & 30.9 & 26.7 & 23.0 & 24.5 & 1.5 & $<0.001$ & 0.07 & 0.35 \\
\hline \multicolumn{9}{|l|}{ Drinking behavior } \\
\hline Water intake (L/12 h) & 43.9 & 47.6 & 79.7 & 74.5 & 3.5 & $<0.001$ & $<0.001$ & 0.30 \\
\hline Drinking bouts (/12 h) & 9.5 & 9.1 & 14.7 & 13.2 & 1.5 & 0.02 & $<0.001$ & 0.24 \\
\hline Drinking interval (min) & 67.9 & 80.2 & 42.1 & 46.7 & 10.4 & 0.35 & $<0.01$ & 0.75 \\
\hline Drink size (L/bout) & 5.1 & 6.7 & 5.7 & 6.0 & 0.7 & 0.09 & 0.19 & 0.66 \\
\hline
\end{tabular}

Therefore, volume of solution infused into the rumen was included in the statistical model as a covariate.

\section{DMI and Feeding Behavior}

Dry matter intake, number of meal bouts, intermeal interval, and meal size were similar between infusion of propionic acid and propionate salts, indicating $\mathrm{pH}$ per se does not have a direct effect on feeding behavior of lactating dairy cows. These results agree with previous observations by Choi and Allen (1999). However, infusion of ammonium propionate decreased DMI compared with infusion of sodium propionate and potassium propionate $(P<0.04$; Table 2$)$. Contrary to our hypothesis, infusion of ammonium did not decrease the hypophagic effect of propionate but resulted in greater hypophagic effects compared with infusion of sodium and potassium. This reduction in DMI was not likely from toxic effects of ammonia because MUN concentrations for the ammonium propionate treatment were within the range of normal values for lactating cows (Butler, 1996). Ammonium infusion increased intermeal interval $(P<$ $0.01)$ and decreased number of meal bouts $(P<0.02)$ compared with sodium propionate and potassium propionate treatments, but did not affect meal size. These observations indicate that the reduction in feed intake from ammonium infusion was from reducing hunger. No difference in DMI and feeding behavior was observed between infusion of sodium and potassium pro- pionate. The amounts of sodium (230 g) or potassium $(391 \mathrm{~g})$ infused over $14 \mathrm{~h}$ are far greater than animal requirements (NRC, 2001), so any possible effects of potassium ions on alleviation of hypophagic effects of propionate are not likely from dietary manipulation.

Before the experiment, we hypothesized that infusion of ammonium propionate would increase DMI compared with other propionate salts because cows infused with ammonium must synthesize additional urea, which consumes 3 moles of ATP per mole of urea synthesized. Greater MUN values for ammonium propionate treatment compared to other treatments $(P<0.001)$ is consistent with greater urea synthesis for cows infused with ammonium propionate. Observed hypophagic effect of ammonium may be explained by increased oxidation of AA in the liver. One of the two amino groups of urea is from ammonia, but the other is from AA via aspartate; urea production in the liver is associated with $\alpha$-amino nitrogen removal in the liver (Reynolds, 1992; Parker et al., 1995). Infusion of $\mathrm{NH}_{4} \mathrm{Cl}$ into the mesenteric vein of sheep increased oxidation of leucine in splanchnic tissues (Lobley et al., 1995). Therefore, urea synthesis might have increased net ATP production in the liver by increasing hepatic AA oxidation, because each turn of tricarboxylic acid cycle generates 12 moles of ATP, while each turn of urea cycle consumes 3 moles of ATP.

Another possible interpretation for the different response in DMI between ammonium treatment and so- 
Table 3. Effects of intraruminal infusion of propionate salts on milk production.

\begin{tabular}{|c|c|c|c|c|c|c|c|c|}
\hline & \multicolumn{4}{|c|}{ Treatments } & \multirow[b]{2}{*}{ SE } & \multicolumn{3}{|c|}{$P$ value } \\
\hline & Control $^{1}$ & Ammonium & Sodium & Potassium & & $\mathrm{A}^{2}$ & $\mathrm{~B}^{3}$ & $\mathrm{C}^{4}$ \\
\hline \multicolumn{9}{|l|}{ Yield } \\
\hline Milk (kg/d) & 36.7 & 31.4 & 31.3 & 33.1 & 2.0 & $<0.01$ & 0.65 & 0.33 \\
\hline Milk fat $(\mathrm{kg} / \mathrm{d})$ & 1.58 & 1.32 & 1.38 & 1.49 & 0.11 & 0.14 & 0.40 & 0.46 \\
\hline Milk protein $(\mathrm{kg} / \mathrm{d})$ & 1.09 & 0.95 & 0.93 & 0.92 & 0.05 & $<0.01$ & 0.73 & 0.94 \\
\hline Milk lactose (kg/d) & 1.69 & 1.47 & 1.48 & 1.46 & 0.09 & 0.03 & 0.99 & 0.88 \\
\hline Milk SNF (kg/d) & 3.09 & 2.69 & 2.68 & 2.65 & 0.16 & 0.02 & 0.90 & 0.90 \\
\hline Milk energy (Mcal/d) & 27.4 & 23.3 & 23.7 & 24.6 & 1.6 & 0.06 & 0.62 & 0.63 \\
\hline Milk energy $(\mathrm{Mcal} / \mathrm{d})$ : & & & & & & & & \\
\hline ME intake $(\mathrm{Mcal} / 12 \mathrm{~h})$ & 0.80 & 0.80 & 0.58 & 0.61 & 0.09 & 0.20 & 0.08 & 0.80 \\
\hline \multicolumn{9}{|l|}{ Composition } \\
\hline Milk fat $(\%)$ & 4.33 & 4.29 & 4.33 & 4.55 & 0.28 & 0.82 & 0.58 & 0.47 \\
\hline Milk protein $(\%)$ & 2.98 & 3.00 & 3.00 & 2.86 & 0.07 & 0.57 & 0.17 & 0.02 \\
\hline Milk lactose (\%) & 4.61 & 4.64 & 4.81 & 4.52 & 0.12 & 0.59 & 0.77 & $<0.01$ \\
\hline Milk SNF (\%) & 8.44 & 8.49 & 8.67 & 8.21 & 0.12 & 0.88 & 0.70 & $<0.01$ \\
\hline Milk urea nitrogen $(\mathrm{mg} / \mathrm{dl})$ & 8.8 & 16.7 & 7.7 & 8.2 & 0.5 & $<0.001$ & $<0.001$ & 0.43 \\
\hline
\end{tabular}

${ }^{1}$ Control: propionic acid.

${ }^{2}$ Comparison between control vs. ammonium, sodium, and potassium.

${ }^{3}$ Comparison between ammonium vs. sodium and potassium.

${ }^{4}$ Comparison between sodium vs. potassium.

${ }^{5} \mathrm{ME}$ intake: total metabolizable energy intake from infusates and diets.

dium and potassium treatments is that infused sodium and potassium increased DMI compared with cows infused with ammonium. Infusion of hyper-physiological concentration of sodium or potassium can increase energy expenditures of animals to maintain homeostasis of blood and normal intracellular concentrations of sodium and potassium. This might have increased propionate oxidation in gut tissues as an energy source and decreased propionate flux to the liver. The gastrointestinal tract accounts for approximately $20 \%$ of total oxygen consumption of the whole body, 30 to $60 \%$ of which has been attributed to ATP-dependent $\mathrm{Na} / \mathrm{K}$ ion-transport systems (Seal and Parker, 2000). Although butyrate is a primary metabolic fuel in ruminal epithelial cells, the extent and type of substrate oxidation depends on concentration of metabolic fuels available to cells (Baldwin and McLeod, 2000). Gut tissues might have oxidized propionate to a greater extent for cows infused with sodium or potassium propionate compared with ammonium propionate. This explanation appears to be supported by tendency for lower milk energy output per metabolizable energy (ME) intake for sodium and potassium treatments compared to ammonium treatment $(P<0.08$; Table 3$)$, which is discussed later.

It is difficult to determine whether DMI was decreased by ammonium treatment compared with sodium and potassium treatments or if DMI was increased by sodium and potassium treatments compared with ammonium treatment in this experiment. We conducted another experiment (Oba and Allen, 2003b) using the same cows with similar infusion protocol except for greater infusion rate for sodium and ammonium
( $16.7 \mathrm{mmol} / \mathrm{min} ; 40 \%$ greater than the infusion rate in this experiment). In that experiment (Oba and Allen, 2003b), DMI was 12.1 and $4.3 \mathrm{~kg} / 12 \mathrm{~h}$, respectively, for sodium propionate and ammonium propionate treatments. This observation does not support the idea that sodium and potassium treatments increased DMI compared to ammonium treatment, because DMI for both treatments was lower when infusion rates of sodium and ammonium were greater compared with this experiment. A more plausible explanation is that ammonium infusion decreased DMI by increased net ATP production in the liver from greater urea synthesis and hepatic AA oxidation.

\section{Chewing and Drinking Activities}

Infusion of ammonium propionate decreased eating time compared to infusion of sodium and potassium propionate $(P<0.03)$, which is consistent with lower DMI for the ammonium treatment. Ruminating time $(P<0.001)$ was lower for infusion of propionate salts compared with propionic acid. Ruminating time per kilogram of DMI was also decreased by infusion of propionate salts compared with propionic acid $(P<0.001)$, but reduction in rumination per kilogram of DMI tended to be greater for sodium and potassium propionate compared with ammonium propionate treatment $(P<0.06)$. However, ruminating time per kilogram of DMI was similar for sodium and potassium treatments. These observations might be attributed to the expected greater osmolarity of ruminal fluid for propionate salt treatments compared with propionic acid treatment 
and for sodium and potassium treatments compared with ammonium treatment, because greater osmotic pressure in ruminal fluid is related to decreased rumination (Welch, 1982). Iso-osmotic infusion of ammonium had less effect on reducing ruminating time as infusion of sodium and potassium, possibly because ammonia was incorporated into microbial protein, reducing the osmolarity of rumen fluid compared with sodium and potassium treatments.

Consistent with treatment effects on ruminating time, infusion of propionate salts increased water intake compared with infusion of propionic acid. Sodium and potassium treatments increased frequency of drinking compared with ammonium treatment, indicated by a greater number of drinking bouts $(P<0.001)$ and decreased interval between bouts $(P<0.01)$. Drink size per bout tended to be greater for infusion of propionate salts compared to propionic acid $(P<0.09)$. Drinking behavior was similar for sodium and potassium treatments. Increased water intake from the infusions is probably because of thirst stimulated by dehydration from translocation of water into the rumen across the osmotic gradient and greater urine output (not measured) to excrete sodium and potassium.

\section{Milk Production}

Infusion of propionate salts decreased milk yield drastically compared with infusion of propionic acid ( $P$ $<0.01$; Table 3). Similarly, yield of milk protein, milk lactose, and milk SNF decreased for cows infused propionate salts compared to propionic acid $(P<0.05)$, although milk composition was not affected by infusion of propionate salts. Reduction in milk yield is partially attributed to lower DMI for ammonium treatment but not for sodium and potassium treatments, because DMI was numerically greater for sodium and potassium treatments compared with the acid treatment. Milk energy output per ME intake tended to be lower for sodium and potassium treatments compared to ammonium treatment $(P<0.08)$, which was similar to the acid treatment. Infused solutions were iso-energetic across treatments, and the difference in energy intake cannot explain our observation. Reduction in milk yield for sodium and potassium treatments can be attributed to greater energy expenditures to maintain homeostasis of blood for osmolarity and ion balance but not attributed to a specific effect of sodium or potassium ion, because milk energy output per Mcal of ME intake was similar for sodium and potassium treatments.

Concentrations of milk protein, milk lactose, and milk SNF were lower for potassium treatment compared with sodium treatment $(P<0.05)$. These reductions in concentration can be attributed to dilution of the milk constituents by a numerically greater milk yield for potassium treatment compared with sodium treatment, because yields of these milk constituents were similar for sodium and potassium treatments. Although milk lactose synthesized in Golgi vesicles of secretory cells is the primary factor determining milk yield by drawing intracellular fluid into the vesicles by osmotic pressure (Holt, 1983), other elements might exert additional osmotic pressure when cows were infused potassium, diluting milk constituents possibly from greater milk fluid production.

\section{CONCLUSIONS}

Contrary to the hypothesis, hypophagic effects of ammonium propionate were greater compared with sodium and potassium propionate. Infusion of ammonium decreased DMI by decreasing meal frequency without affecting meal size, indicating that ammonium decreased hunger. No difference in DMI and feeding behavior was observed between infusion of sodium and potassium propionate at concentrations greater than practical for diet formulation, indicating that any possible effects of sodium or potassium ions on feeding behavior are not likely from dietary manipulation.

\section{ACKNOWLEDGMENTS}

Acknowledgment is made to the Michigan Agricultural Experiment Station for financial support of this research. The authors thank R. E. Kreft and D. G. Main for technical assistance.

\section{REFERENCES}

Allen, M. S. 2000. Effects of diet on short-term regulation of feed intake by lactating dairy cattle. J. Dairy Sci. 83:1598-1624.

Anil, M. H., and J. M. Forbes. 1980. Feeding in sheep during intraportal infusions of short-chain fatty acids and the effect of liver denervation. J. Physiol. 298:407-414.

Anil, M. H., and J. M. Forbes. 1988. The roles of hepatic nerves in the reduction of food intake as a consequence of intraportal sodium propionate administration in sheep. Q. J. Exp. Physiol. 73:539546.

ASAE 1968. Method of determining and expressing fineness of feed material by sieving. ASAE Standard S319.

Baldwin, R. L. VI, and K. R. McLeod. 2000. Effects of diet forage:concentrate ratio and metabolizable energy intake on isolated rumen epithelial cell metabolism in vitro. J. Anim. Sci. 78:771-783.

Butler, W. R., J. J. Calaman, and S. W. Beam. 1996. Plasma and milk urea nitrogen in relation to pregnancy rate in lactating dairy cattle. J. Anim. Sci. 74:858-865.

Choi, B. R., and M. S. Allen. 1999. Intake regulation by volatile fatty acids and physical fill. S. Afr. J. Anim. Sci. 29(ISRP):4041(Abstr.).

Hach, C. C., B. K. Bowden, A. B. Lopelove, and S. V. Brayton. 1987. More powerful peroxide Kjeldahl digestion method. J. AOAC 70:783-787.

Holt, C. 1983. Swelling of Golgi vesicles in mammary secretory cells and its relation to the yield and quantitative composition of milk. J. Theor. Biol. 101:247-261. 
Karkalas, J. 1985. An improved enzymatic method for the determination of native and modified starch. J. Sci. Food Agric. 36:10191027.

Koch, J. E., H. Ji, M. D. Osbakken, and M. D. Friedman. 1998. Temporal relationships between eating behavior and liver adenine nucleotides in rats treated with 2,5-anhydro-D mannitol. Am. J. Physiol. 274:R610-R617.

Langhans, W., F. Wiesenreitter, and E. Scharrer. 1983. Different effects of subcutaneous D,L-3-hydroxybutyrate and acetoacetate injections on food intake in rats. Physiol. Behav. 31:483-486.

Langhans, W., U. Damaske, and E. Scharrer. 1984. Subcutaneous glycerol injection fails to reduce food intake in rats fed a high protein diet. Physiol. Behav. 32:785-789.

Langhans, W., U. Damaske, and E. Scharrer. 1985a. Different metabolites might reduce food intake by the mitochondrial generation of reducing equivalents. Appetite 6:143-152.

Langhans, W., G. Egli, and E. Scharrer. 1985b. Selective hepatic vagotomy eliminates the hypophagic effect of different metabolites. J. Auton. Nerv. Sys. 13:255-262.

Langhans, W., and E. Scharrer. 1987. Evidence for a role of the sodium pump of hepatocytes in the control of food intake. J. Auton. Nerv. System 20:199-205.

Lobley, G. E., A. Connell, M. A. Lomax, D. S. Brown, E. Milne, A. G. Calder, and D.A.H.F. Farningham. 1995. Hepatic detoxification of ammonia in the ovine liver: possible consequences for amino acid catabolism. Br. J. Nutr. 73:667-685.

National Research Council. 1989. Nutrient Requirements of Dairy Cattle. 6th rev. ed. Natl. Acad. Sci., Washington DC.
National Research Council. 2001. Nutrient Requirements of Dairy Cattle. 7th rev. ed. Natl. Acad. Sci., Washington DC.

Niijima, A. 1983. Glucose-sensitive afferent nerve fibers in the liver and their role in food intake and blood glucose regulation. J. Auton. Nerv. Sys. 9:207-220.

Oba, M., and M. S. Allen, 2003a. Intraruminal infusion of propionate alters feeding behavior and decreases energy intake of lactating cows. J. Nutr. 133: in press.

Oba, M., and M. S. Allen, 2003b. Hypophagic effects of ammonium are greater when infused with propionate compared to acetate in lactating dairy cows. J. Nutr. 133: in press.

Parker, D. S., M. A. Lomax, C. J. Seal, and J. C. Wilton. 1995. Metabolic implications of ammonia production in the ruiminant. Proc. Nutr. Soc. 54:549-563.

Reynolds, C. K. 1992. Metabolism of nitrogenous compounds by ruminant liver. J. Nutr. 122:850-854.

Seal, C. J., and D. S. Parker. 2000. Influence of gastrointestinal metabolism on substrate supply to the liver. Pages 131-148 in Ruminant Physiology: Digestion, Metabolism, Growth, and Reproduction. P. B. Cronje ed. CABI Publishing, New York, NY.

Van Soest, P. J., J. B. Robertson, and B. A. Lewis. 1991. Methods for dietary fiber, neutral detergent fiber, and nonstarch polysaccharides in relation to animal nutrition. J. Dairy Sci. 74:35833597.

Welch, J. G. 1982. Rumination, particle size, and passage from the rumen. J. Anim. Sci. 54:885-894.

Wildman, E. E., G. M. Jones, P. E. Wagner, R. L. Boman, H. F. Troutt, Jr., and T. N. Lesch. 1982. A dairy cow body condition scoring system and its relationship to selected production characteristics. J. Dairy Sci. 65:495-501. 